$1-1-1973$

\title{
The effects of parent rock type and site quality upon resistance to decay of oak wood
}

\author{
W. C. Percival \\ Earl H. Tryon \\ R. P. true
}

Follow this and additional works at: https://researchrepository.wvu.edu/ wv_agricultural_and_forestry_experiment_station_bulletins

\section{Digital Commons Citation}

Percival, W. C.; Tryon, Earl H.; and true, R. P., "The effects of parent rock type and site quality upon resistance to decay of oak wood" (1973). West Virginia Agricultural and Forestry Experiment Station Bulletins. 624T.

https://researchrepository.wvu.edu/wv_agricultural_and_forestry_experiment_station_bulletins/711 @ WVU. It has been accepted for inclusion in West Virginia Agricultural and Forestry Experiment Station Bulletins by an authorized administrator of The Research Repository @ WVU. For more information, please contact ian.harmon@mail.wvu.edu. 


\section{he Effects of}

\section{arent Rock Type and ite Quality Upon lesistance to Decay of Oak ${ }^{2}$ Wood AG. ENGR. LIBRARY WEST VIRGINIA UNIVERSITY}

\section{ULLETIN 624T}

iptember 1973

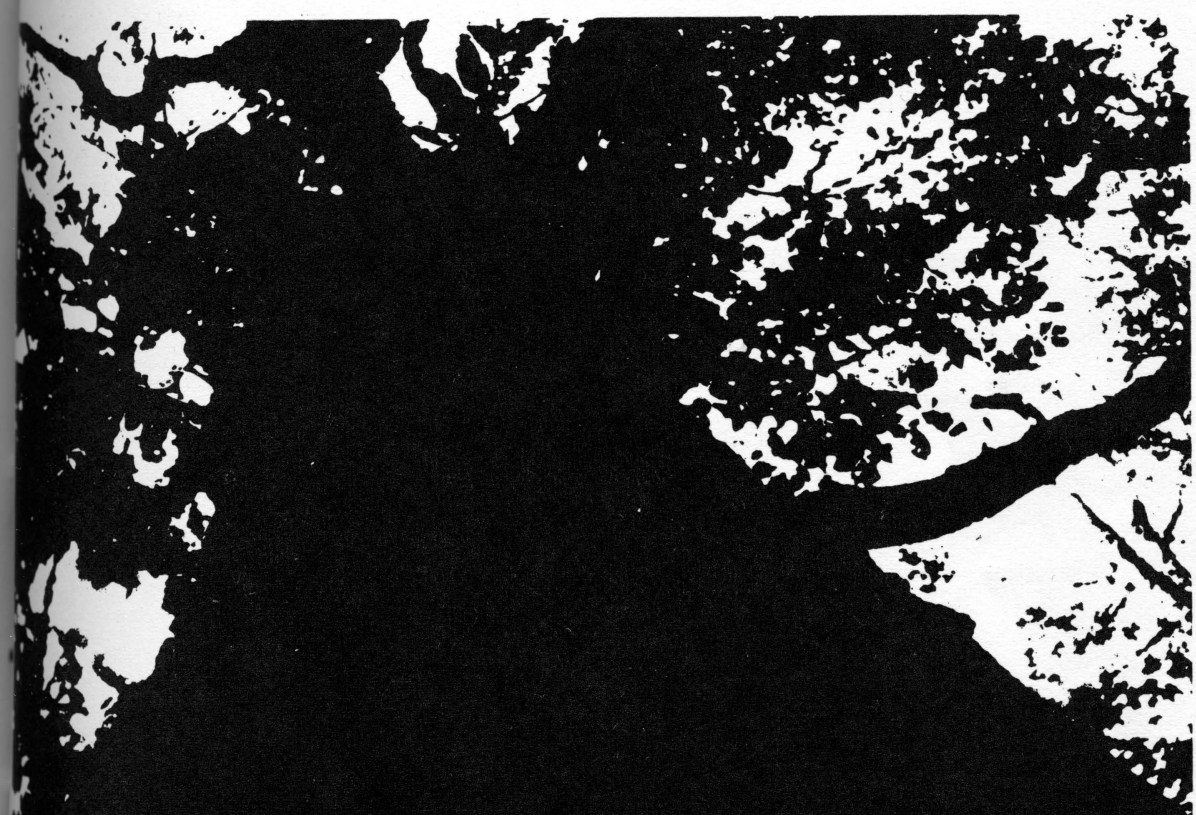

West Virginia University Agricultural Experiment Station 


\section{THE AUTHORS}

W. C. Percival is Professor Emeritus of Forestry and formerly Director of the Division of Forestry; E. H. Tryon is Silviculturist; and R. P. True is Professor Emeritus of Plant Pathology and formerly Plant Pathologist.

\section{ACKNOWLEDGMENTS}

Acknowledgment is made of the substantial assistance given by Dr. C. B. Koch and Dr. J. R. Hamilton, particularly in respect to the hygroscopicity of wood samples; also that given by Dr. H. L. Barnett for his suggestion of cultural techniques which would avoid influence of extraneous nutrients upon the actions of inoculants upon wood samples.

The senior author wishes to acknowledge the inspiration of his former teacher in the late 1920s, Dr. L. H. Pennington, who developed his motivating curiosity concerning the relationships of wood-destroying fungi to their hosts.

West Virginia University Agricultural Experiment Station College of Agriculture and Forestry

R. S. Dunbar, Jr., Director

Morgantown 


\title{
The Effects of
}

Parent Rock Type and

Site Quality

Upon Resistance to

Decay of Oak Wood

\author{
W. C. Percival, E. H. Tryon, and R. P. True
}

The purpose of this study was to find if the rock types and the growth-influencing qualities of the sites on which trees have grown affect the decay resistance of the wood produced by them.

Oak wood was chosen as the host material because it is the most important wood produced in the Appalachian Hardwood Region and because considerable work with it in the area of decay resistance has been accomplished by others.

The red oak group of woods is known to be susceptible to decay, whereas the white oaks are relatively durable. Boyce (1961) recognizes the classification of woods according to decay resistance which places red oak with the group having low resistance and white oak with those having intermediate resistance (Anonymous 1950). For centuries the strength, beauty, and finishing qualities of most oak woods have made them desirable for furniture, interior trim, and dry flooring. Only the white oaks have been useful for purposes where natural decay resistance was necessary, such as for boat timbers, posts, piles and railroad ties. In recent years, wood preservatives have made red oaks useful for some of these purposes.

Buyers of standing timber have long been cognizant of the durability of white oak but looked particularly for it growing on fertile limestone soils because they believed that on such soils any decay which had entered the tree would not "run far" as it would do in white oak trees located on other soils.

Scheffer, Englerth, and Duncan (1949) found that "although considerable differences (in the decay resistance of oak) were found among regions as a whole, they were generally no greater than among localities within regions." Since certain site factors differ as much between localities within regions as they do between regions, this suggests the possibility of the influence of site on decay resistance. 
Merrill and Cowling (1966) have demonstrated that natural variation in the nitrogen content of wood affects its resistance to decay. Differences in the amount of available nitrogen in the soil may result in such natural variation. $A$ higher incidence of heart rot was found by Boyce and Wagg (1953) in Douglas-fir (Pseudotsuga menziesii [Mirb.] Franco) growing on soils with a high nitrogen content than on soils with less nitrogen.

Such findings indicated that variations in site characteristics may be expected to affect resistance to decay in wood but very little proof has been offered. Toole and Darwin (1970) while working on the "Influence of Variation in Physical and Chemical Properties of Southern Red Oak Lumber on Decay Resistance" found correlations between certain wood characteristics and decay resistance at the 1 per cent level of significance but made no mention of the growing sites from which the wood had been secured other than location by states.

The site characteristics considered in this study were the geologic formation from which the soil was derived and the relative moisture content and fertility.

\section{MATERIALS AND METHODS}

Test samples of wood were obtained from standing trees rather than from sawed lumber only for the assurance that each tree was located upon a site, the soils of which were derived from a single, definite rock type, that the type could be classified as moist-high quality or dry-low quality, and that the samples came from the same position in each tree.

Suitable sites were found in the north-central area of West Virginia where the topography is rough, the elevations range between 2,200 and 3,000 feet above sea level, and the precipitation averages about $\mathbf{5 0}$ inches annually. Soils in this area are derived mostly from acid sandstones and shales with an average $\mathrm{pH}$ of 4.6 and to a lesser extent from limestone with an average $\mathrm{pH}$ of 6.5 (Yawney 1964). In the captions for the tables and figures for this study, the term "sandstone" is used to designate both of the acid rock types because they are mixed somewhat and sandstone was the dominant influence in soil formation of the acid sites from which the wood samples were obtained.

Two species of oak were used: white oak (Quercus alba L.) and northern red oak ( $Q$. rubra L.). Each of these species was located on four different sites making a total of eight sites. Ten healthy sample trees were selected at random on each site. From each tree, three wood samples were taken, making a total of 240 samples (Table 1 ).

\section{Collection, Transportation and Storage of Material}

Samples of wood were collected as increment borer cores, 0.21 inch in diameter and approximately 2 inches in length. The three cores from each tree were taken one inch apart in a vertical row parallel with the grain and at a height 
TABLE 1

Sample Tree Site Characteristics

\begin{tabular}{|c|c|c|c|c|}
\hline $\begin{array}{l}\text { Sample } \\
\text { Tree Species }\end{array}$ & $\begin{array}{l}\text { Associated } \\
\text { Tree Species }\end{array}$ & Soil Type & Derived From & $\begin{array}{c}\text { Site } \\
\text { Quality } \\
\text { Index }\end{array}$ \\
\hline White Oak & $\begin{array}{l}\text { Yellow-poplar } \\
\text { Red Oak } \\
\text { Sugar maple }\end{array}$ & $\begin{array}{l}\text { Belmont } \\
\text { Silt } \\
\text { Loam }\end{array}$ & $\begin{array}{l}\text { Greenbrier } \\
\text { Limestone }\end{array}$ & 75 \\
\hline White Oak & $\begin{array}{l}\text { Shell-bark hickory, } \\
\text { Red oak, Black } \\
\text { locust, Sugar maple, } \\
\text { Mockernut hickory }\end{array}$ & $\begin{array}{l}\text { Belmont } \\
\text { Silt } \\
\text { Loam }\end{array}$ & $\begin{array}{l}\text { Greenbrier } \\
\text { Limestone }\end{array}$ & 60 \\
\hline White Oak & $\begin{array}{l}\text { Sugar maple, Yellow } \\
\text { birch, Red oak, } \\
\text { Eastern hemlock } \\
\text { Cucumber }\end{array}$ & $\begin{array}{l}\text { Laidig Loam } \\
\text { Pope Sandy Loam }\end{array}$ & $\begin{array}{l}\text { Catskill } \\
\text { Shale }\end{array}$ & 78 \\
\hline White Oak & $\begin{array}{l}\text { Chestnut oak, Black } \\
\text { oak, Mockernut } \\
\text { hickory, Pitch pine } \\
\text { Dogwood }\end{array}$ & Ramsey Loam & $\begin{array}{l}\text { Catskill } \\
\text { Shale }\end{array}$ & 43 \\
\hline Red Oak & $\begin{array}{l}\text { Yellow poplar } \\
\text { Black cherry }\end{array}$ & $\begin{array}{l}\text { Belmont } \\
\text { Silt Loam }\end{array}$ & $\begin{array}{l}\text { Greenbrier } \\
\text { Limestone }\end{array}$ & 80 \\
\hline Red Oak & $\begin{array}{l}\text { Hickory } \\
\text { White ash } \\
\text { Yellow-poplar }\end{array}$ & $\begin{array}{l}\text { Belmont } \\
\text { Silt Loam }\end{array}$ & $\begin{array}{l}\text { Greenbrier } \\
\text { Limestone }\end{array}$ & 63 \\
\hline Red Oak & $\begin{array}{l}\text { Black cherry } \\
\text { Yellow-poplar }\end{array}$ & $\begin{array}{l}\text { Dekalb } \\
\text { Sandy Loam }\end{array}$ & $\begin{array}{l}\text { Pottsville } \\
\text { Sandstone }\end{array}$ & 94 \\
\hline Red Oak & $\begin{array}{l}\text { Chestnut oak } \\
\text { Scarlet oak }\end{array}$ & $\begin{array}{l}\text { Dekalb } \\
\text { Sandy Loam }\end{array}$ & $\begin{array}{l}\text { Pottsville } \\
\text { Sandstone }\end{array}$ & 75 \\
\hline
\end{tabular}


of $41 / 2$ feet from the ground. The bark, sapwood and one outer ring of heartwood were discarded so that each sample core started with the second annual ring of heartwood and extended radially toward the pith. The heartwood was differentiated from the sapwood by use of methyl-orange in any case where the difference in natural coloration of the wood was insufficient for its identification. Before removing the core the old bark was removed down to clean young bark with a hatchet. The core was taken with a new sharp increment borer which had been sterilized in alcohol. Each core was placed in a sterilized test tube for transportation and storage. Cores were examined under a $3 \mathrm{X}$ lens to determine the number of annual rings per inch (ring frequency).

All cores were stored at $0^{\circ} \mathrm{C}$ and remained in storage until the entire number was obtained from all sites. They were all processed under the same conditions at the same time insofar as the time lapse necessary for drying and weighing would permit.

It was considered possible that storage of the increment cores might affect their resistance to decay; therefore, a test was made to find if this had occurred. An additional series of ten red-oak cores were taken one inch above the same places on the same trees as the regular red-oak series on the low-quality, sandstone site and inoculated with $L$. trabea Fr. The average loss of weight of the increment cores in the regular series which had been kept in storage was 20.30 per cent of dry weight, whereas the average loss of weight of the unstored series was $\mathbf{2 0 . 1 5}$ per cent of dry weight. The results were so nearly identical that the storage of sample increment cores by the method used in this study was considered to have no effect on their resistance to decay.

\section{Drying, Weighing, Rehydrating and Sterilizing}

As noted by Scheffer, Englerth, and Duncan (1949), cores with a diameter of 0.21 inch appeared to give as reliable results as larger samples if they were weighed more accurately. After considerable experimentation with similar specimens the most accurate results for this study were obtained by drying the cores over phosphorus pentoxide $\left(\mathrm{P}_{2} \mathrm{O}_{5}\right)$.

The cores were placed in weighing bottles in desiccators with equal amounts of $\mathrm{P}_{2} \mathrm{O}_{5}$ taken directly from the sealed bottles bearing the same warranted analysis of the manufacturer (Fisher Scientific Co.). The cores were weighed at 24-hour intervals until two consecutive weights were obtained to within three ten-thousandths of a gram (.0003 g.) on a Sartorius automatic balance. All exposures of wood samples and desiccant were under uniform atmospheric conditions and time schedules.

The cores were then rehydrated for one day over distilled water, after which they were sterilized in an autoclave for 20 minutes at $100^{\circ} \mathrm{C}$ and 0 pounds pressure. After sterilization and before inoculation, 30 sample cores chosen at random were weighed. It was found that the cores then held water from 27 per 
cent to 78 per cent of their dry weight. After these cores had been decayed and per cent weight losses were known, it was found there was no correlation between per cent weight loss due to decay and this variation in water of hydration in the cores at the time they went into culture. This indicated that the considerable variation in the per cent water content of the cores as they went into culture did not affect the weight loss due to decay.

\section{Decay Organisms and Inoculation}

Polyporus versicolor Fr. (Wash. 12679 or Madison 697 isolate) and Lenzites trabea Fr. (Wash. 11539 or Madison 617 isolate) were used because they are well-known destroyers of oak timbers and because of their significance in previous publications (Scheffer, Englerth, and Duncan 1949), (Toole and Duncan 1970). Scheffer, Englerth, and Duncan recommended $P$. versicolor as a test fungus for any broad-leaved tree species whereas $L$. trabea was very strongly inhibited in white oak as shown by their Table 1, p. 138. These fungi, particularly $P$. versicolor, are found on hardwood timbers in the Appalachian area. For these reasons, sub-cultures of the same isolates as those used in the above study. (Washington 12679 and Washington 11539) were obtained from the American Type Culture Collection and were used exclusively in the present study.

These fungi were cultured on glucose-yeast-extract medium (10 g. glucose, 2 g. yeast extract, $19 \mathrm{~g}$. agar, 1 liter distilled water). Test tubes, $20 \times 125 \mathrm{~mm}$., with screw caps, were used for inoculating and incubating the fungi on the sample cores. A carefully measured $5 \mathrm{cc}$. of the glucose-yeast-extract medium was poured into each test tube and allowed to cool while lying horizontal, the shoulder on the test tube preventing the small amount of medium from coming into the neck or cap. The tubes were always stored, transported, and used for incubation purposes in an approximately horizontal position. The medium in one-third of the tubes was inoculated with $P$. versicolor, another one-third with $L$. trabea and one-third remained sterile as a control. The inoculants were allowed to incubate for about three weeks during which time they formed a mat of mycelium completely covering the medium. It would be expected that they would also have exhausted the nutrients from such a small amount of medium.

The sample cores (with about $27^{+}$per cent water content) were then placed upon the glass sides of the tubes where they could lie in contact with the aerial hyphae from the mycelial mats.

\section{Incubation, Drying and Weighing}

All of the cultures and controls were incubated together for four months in a stainless steel culture chamber designed especially for the purpose of maintaining them under the same uniform conditions of temperature, humidity, and light (Figure 1). The culture chamber was on a table in a research laboratory where 
the temperatures varied from $70^{\circ}$ to $80^{\circ} \mathrm{F}$. The humidity was maintained by evenly distributing eight open battery jars of distilled water inside the chamber and suspending fiber-glass wicks between the battery jars and over the tubes containing the cultures and controls. The relative humidity was tested with a pocket hygrometer and was found to be distributed evenly and constantly from 80 to 95 per cent except during brief periods when the chamber was opened for inspection. The cultures were in total darkness except during these brief periods. The tubes were oriented as shown in Figure 1 so that they were equally exposed to light and equally accessible. The culture chamber was not air-tight. It allowed a slight interchange of air around the lid but was tight enough to maintain control of humidity and to prevent contamination.

Immediately after incubation, 16 cores, which had been tested previously to determine the per cent water of hydration before inoculation, were weighed again to determine the per cent water of hydration based on dry weight of decayed core. This varied from $\mathbf{7 4 . 5}$ to $\mathbf{1 8 3 . 6}$ per cent. There was no correlation between per cent water of hydration either before or after incubation and per cent loss of dry weight by decay. This appears to indicate that there was neither too little nor too much water in the wood samples to influence sufficiently the rate of decay to mask the effects of the site factors being tested.

After four months incubation the cores were dried to constant weight over $\mathrm{P}_{2} \mathrm{O}_{5}$ as previously described.

\section{Analysis of Data}

In ring-porous hardwoods such as the oaks, the ring width is related directly to the average specific gravity of the wood (Panshin and DeZeeuw 1964). The relation between specific gravity and decay as it affects wood from different trees of the same species is still unsettled (Boyce 1961, Zabel 1948); therefore, the possibility of ring frequency affecting decay was recognized in the analysis of data. An analysis of covariance of the data was performed, holding ring frequency constant, for indications of correlations between weight loss from decay and site factors. 
FIGURE 1. Culture chamber made expressly for the purpose of holding tubed cultures, all of which are in the same conditions of temperature, humidity, and light.

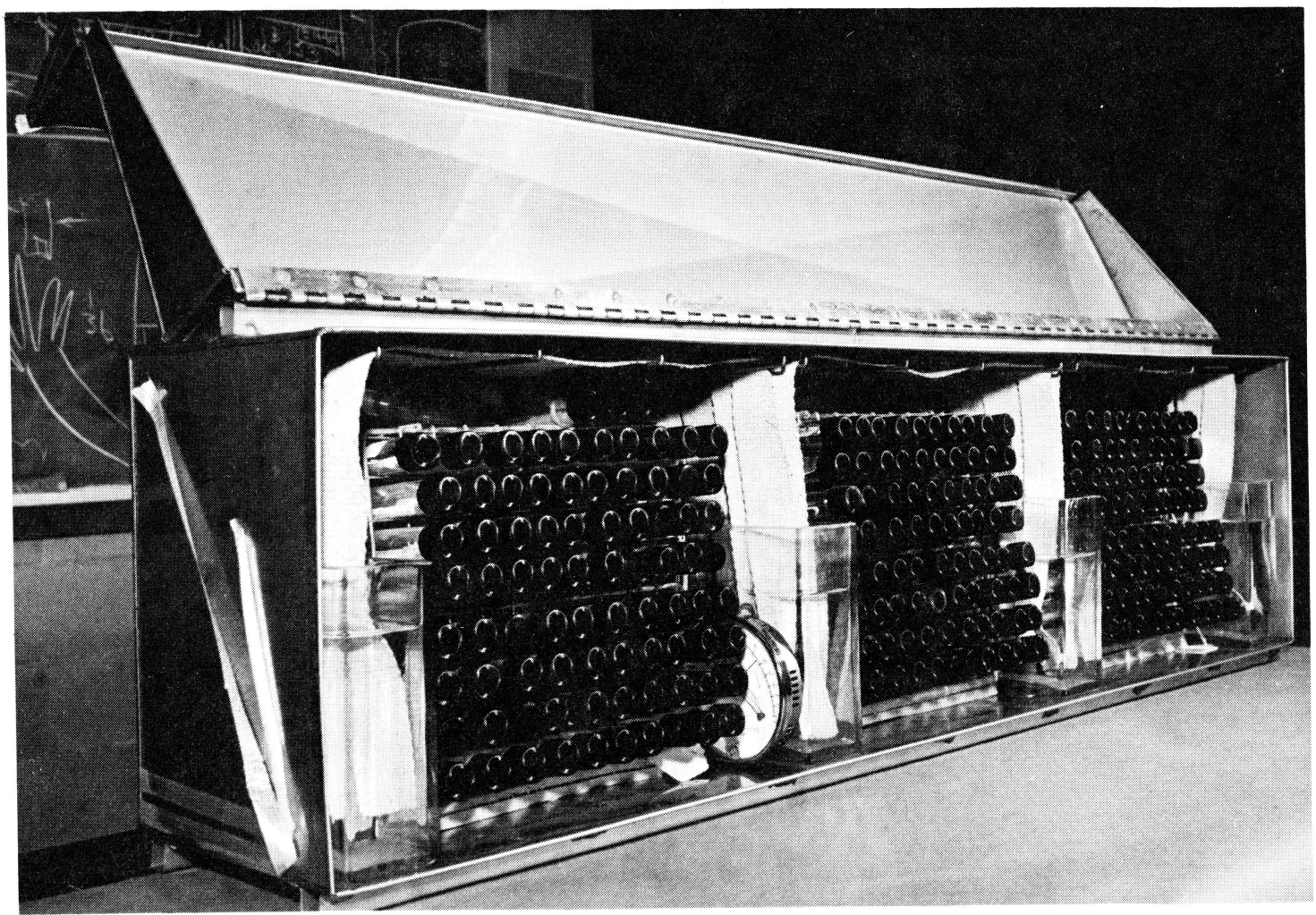




\section{RESULTS}

The extent of decay of the inoculated wood samples is indicated by per cent loss of dry weight. The greater weight-loss indicates the greater extent of decay. The weight-loss data were classified by ten-sample groups, including in each group all samples which had come from the same site (Table 1), which were produced by the same host species, and which were decayed by the same fungous isolate. The mean weight-loss per cent of each of the 16 ten-sample groups is shown in Table 2. When these data were computed with the number of annual rings per inch held constant, the values were changed as shown in Table 3 and Figure 2. Thus classified, the means of the ten-sample groups as shown in Table 3 and Figure 2 were tested by analysis of covariance and were found to be statistically significant. ${ }^{1}$

Three increment cores to serve as wood samples were taken from each of the 80 trees used in this study, one for inoculation with $L$. trabea, one with $P$. versicolor and one for a control. The mean weight-loss per cents of these three-sample groups were tested by analysis of covariance. This test showed no significance, therefore it is only when the weight-loss per cents of the wood samples are classified as described above by site characteristics, host species, and decay organisms that they have statistical significance.

It was a purpose of this study to find if the parent rock types from which the soils of forest sites are derived affect the decay resistance of the wood produced on them. The answer to this question for the specific sites, host woods, and decay organisms studied here is available in Table 3 or in Figure 2. For example, the mean of a ten-sample group of red oak cores taken from ten trees growing on a high-quality, sandstone site when decayed by $L$. trabea had a significant loss in weight of 26.21 per cent; a mean of another ten-sample group of red oak cores taken from ten trees growing on a high-quality, limestone site when decayed under the same conditions by the same isolate of $L$. trabea had a significant loss in weight of 40.27 per cent. The red oak samples from trees grown on the limestone site had a loss in weight $\mathbf{5 3 . 6 4}$ per cent greater than those grown on the sandstone site. Therefore red oak wood from the limestone site had less decay resistance than that from the sandstone site.

It is interesting to note the regularity of the decrease in the per cent loss of weight of red oak samples decayed by $L$. trabea as seen in Figure 2. When they were grown on limestone, high-quality sites, they lost 40.27 per cent of their weight; on limestone, low-quality sites, they lost 33.51 per cent, which is nearly 7 per cent less; on acid, high-quality sites, they lost 26.21 per cent, which is a

${ }^{1}$ Statistical significance in this paper was determined at the 5 and 1 per cent levels. All significant differences were found to exceed the 1 per cent level unless otherwise stated. 


\section{TABLE 2}

Weight-Loss Per Cents Caused by Decay of Oak Wood Samples from Eight Different Sites. Each Value Is An Average of Ten Samples

\begin{tabular}{|c|c|c|c|c|c|c|c|c|}
\hline \multirow[b]{3}{*}{ Decay fungi } & \multicolumn{4}{|c|}{ Limestone Sites } & \multicolumn{4}{|c|}{ Sandstone Sites } \\
\hline & High C & 2uality & Low $\mathrm{C}$ & Quality & High O & 2uality & Low $\mathrm{C}$ & 2uality \\
\hline & $\begin{array}{l}\text { Red } \\
\text { Oak }\end{array}$ & $\begin{array}{c}\text { White } \\
\text { Oak }\end{array}$ & $\begin{array}{l}\text { Red } \\
\text { Oak }\end{array}$ & $\begin{array}{c}\text { White } \\
\text { Oak }\end{array}$ & $\begin{array}{l}\text { Red } \\
\text { Oak }\end{array}$ & $\begin{array}{l}\text { White } \\
\text { Oak }\end{array}$ & $\begin{array}{l}\text { Red } \\
\text { Oak }\end{array}$ & $\begin{array}{l}\text { White } \\
\text { Oak }\end{array}$ \\
\hline zites trabea & 40.11 & 7.26 & 33.36 & 12.09 & 26.00 & 9.60 & 20.30 & 3.58 \\
\hline Olyporus versicolor & 39.99 & 18.04 & 12.35 & 46.23 & 21.96 & 32.88 & 13.55 & 25.17 \\
\hline iontrol & 0.79 & 0.65 & 1.69 & 0.14 & 1.14 & 0.48 & 1.58 & 0.94 \\
\hline
\end{tabular}

\section{TABLE 3}

Weight-Loss Per Cents Caused By Decay of Oak Wood Samples from Eight Different Sites Computed With Number of Rings Per Inch Held As A Constant. Each Value Is An Average of Ten Samples. Differences Are Siginificant At the 1 Per Cent Level

\begin{tabular}{|c|c|c|c|c|c|c|c|c|}
\hline \multirow[b]{3}{*}{ Decay fungi } & \multicolumn{4}{|c|}{ Limestone Sites } & \multicolumn{4}{|c|}{ Sandstone Sites } \\
\hline & \multicolumn{2}{|c|}{ High Quality } & \multicolumn{2}{|c|}{ Low Quality } & \multicolumn{2}{|c|}{ High Quality } & \multicolumn{2}{|c|}{ Low Quality } \\
\hline & $\begin{array}{l}\text { Red } \\
\text { Oak }\end{array}$ & $\begin{array}{l}\text { White } \\
\text { Oak }\end{array}$ & $\begin{array}{l}\text { Red } \\
\text { Oak }\end{array}$ & $\begin{array}{l}\text { White } \\
\text { Oak }\end{array}$ & $\begin{array}{l}\text { Red } \\
\text { Oak }\end{array}$ & $\begin{array}{c}\text { White } \\
\text { Oak }\end{array}$ & $\begin{array}{l}\text { Red } \\
\text { Oak }\end{array}$ & $\begin{array}{l}\text { White } \\
\text { Oak }\end{array}$ \\
\hline Lenzites trabea & 40.27 & 7.21 & 33.51 & 12.28 & 26.21 & 9.34 & 20.50 & 2.91 \\
\hline Polyporus versicolor & 40.15 & 20.76 & 12.50 & 46.46 & 22.16 & 32.65 & 13.75 & 24.45 \\
\hline Control & 0.95 & 0.68 & 1.85 & 0.35 & 1.34 & 0.21 & 1.78 & 0.32 \\
\hline
\end{tabular}


little more than 7 per cent less; on acid, low-quality sites, they lost 20.50 per cent, which is nearly 6 per cent less. The white oak host species or the $P_{\text {e }}$ versicolor decay fungus display no such regularity in their reactions but they have other unique relationships which portray their individualities.

The most important unique relationship seems to be the very strong decay resistance of white oak wood from high-quality, limestone sites (Figure 2). Its susceptibility to decay is less than half that of white oak wood from low-quality, limestone sites, less than two-thirds that of white oak wood from high-quality, sandstone sites, and within about 2 per cent of that of the white oak wood from low-quality, sandstone sites which by all tests produced the most decay-resistant wood of all sites tested. The observations of experienced timber buyers that decay would not "run far" in white oak on fertile, limestone soils as mentioned previously in this bulletin are strongly supported.

The ten-sample group of white oak wood from a low-quality, limestone site suffered more decay by $P$. versicolor than any other ten-sample group under any conditions used in this study.

FIGURE 2. Weight-loss per cents given in Table 3 indicating extent of decay of oak samples from eight sites differing in parent rock types and tree-growth qualities. Each value is an average of ten samples.

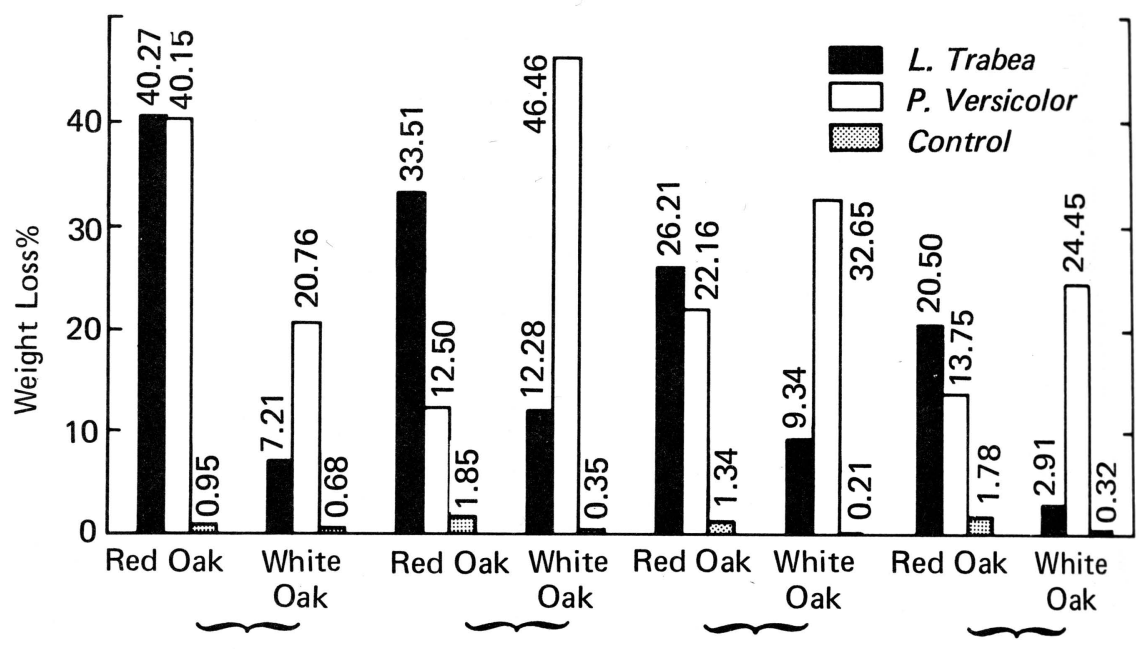

High Quality Low Quality High Quality Low Quality

Limestone Sites

Sandstone Sites 
The relative importance of the four factors affecting decay resistance which have been considered in this study are indicated by fourteen additional tests. Each of these tests by analysis of covariance utilized all 160 wood samples which had been in culture. They differed only by the manner in which they were separated into groups according to the four factors: parent rock types (limestone or sandstone), site quality (high or low), host woods (red or white oak), and decay organisms ( $L$. trabea or $P$. versicolor). The tests are in three series:

(1) Four tests in each of which the wood samples were separated into two groups of 80 samples each according to one of the four factors while the other three factors remained ungrouped.

(2) Four tests in each of which the wood samples were separated into eight groups of $\mathbf{2 0}$ samples each according to three of the four factors while the other one factor remained ungrouped.

(3) Six tests in each of which the wood samples were separated into four groups of 40 samples each according to two of the four factors while the other two factors remained ungrouped.

FIGURE 3. Weight-loss per cents caused by decay of oak samples by various dassifications. All differences were significant at the 1 per cent level except (b) [Site Quality] which was significant at the 5 per cent level.

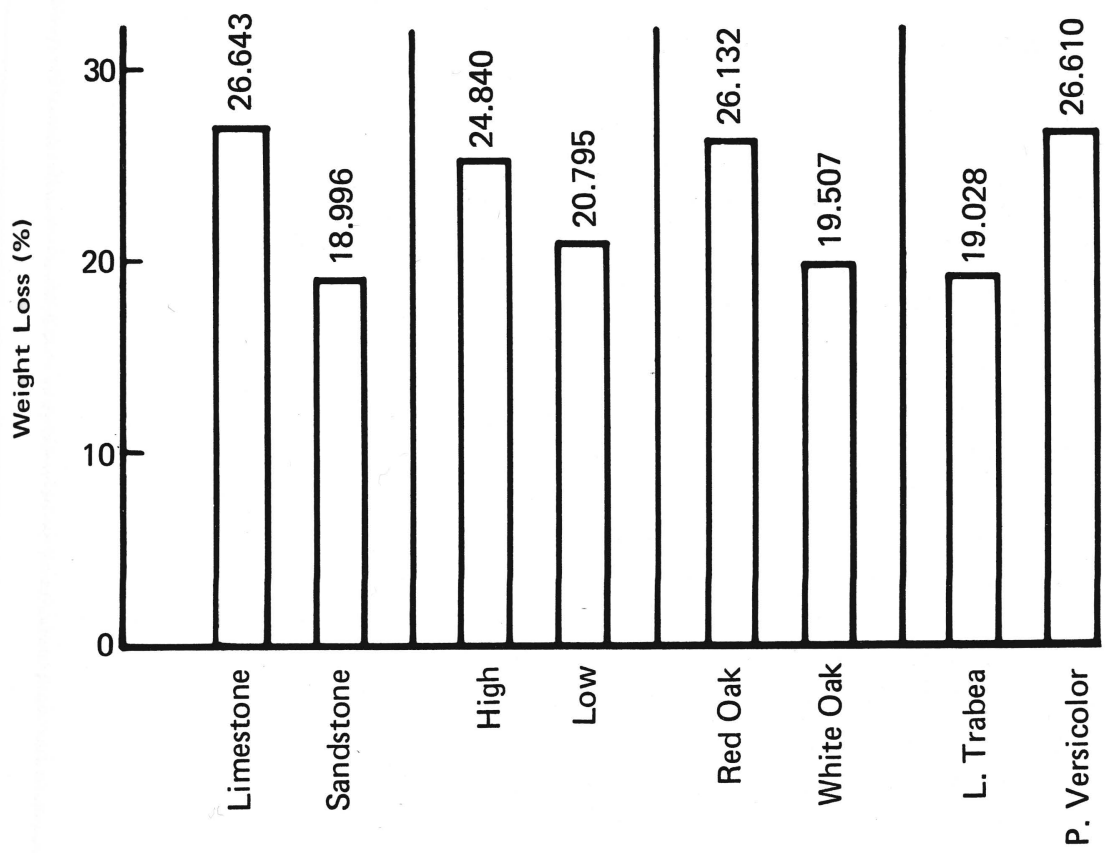

$\begin{array}{llll}\text { (a) Parent Rock } & \text { (b) Site Quality } & \text { (c) Species } & \text { (d) Decay }\end{array}$ 
Starting with Series 1 , the data from the 160 samples which had been inoculated were separated into two groups of $\mathbf{8 0}$ samples each according to the type of rock from which the soils of the sites were derived (Figure 3 [a]). The mean of the 80 samples from four limestone sites had a loss in weight of 40.26 per cent more than the mean of the $\mathbf{8 0}$ samples from four sandstone sites. Therefore the decay resistance of the wood from the limestone sites was less than that from the sandstone sites and the difference was significant at the 1 per cent level.

When the 160 samples which had been inoculated were separated into two, 80-sample groups according to the single criterion of site quality, they were found to be more resistant to decay if they had come from trees on low-quality sites. The difference was about 20 per cent as shown in Figure 3 [b] , however, this was significant at only the 5 per cent level. The unique relationship of white oak wood previously described wherein it was much more resistant to decay if it came from high-quality, limestone sites than if was if it came from low-quality, limestone sites is directly contrary to the result shown in Figure 4. This is sufficient to cause the lower level of significance.

When the 160 wood samples which had been inoculated were separated into two groups by the one criterion of host wood, the red oak was found to be more susceptible to decay than the white oak by 34 per cent (Figure $3[\mathrm{c}]$ ).

A test of the 160 samples when separated by the single criterion of decay organisms showed that $P$. versicolor was by nearly 40 per cent a more virulent destroyer of the oak samples than $L$. trabea (Figure $3[d]$ ). It may be seen in Figure 2 that red oak from low-quality sites is somewhat resistant to $P$. versicolor, however, white oak from all sites is very resistant to $L$. trabea.

Series 2 begins with a test by which three of the four factors were separated into eight groups of $\mathbf{2 0}$ samples each while the parent rock types, that is, the limestone and sandstone sites, were not separated. Figure 4 shows that this omission of separate groups for limestone and sandstone parent rock types did not cause sufficient inconstancy of data to prevent a significance at the 1 per cent level. It should be noted that only red oak wood from high-quality sites is much more susceptible to decay than that from low-quality sites. White oak susceptibility to decay is somewhat greater on low-quality sites. The reason for the low significance of the differences shown in Figure 3 [b] becomes apparent.

Another test in Series 2 showed that the omission of the separation of high-quality from low-quality sites created inconstancy of data sufficient to result in no significance. The combination of high-quality site with low-quality site data on a limestone site throws together in a 20-sample unit the 10-sample group with the highest weight-loss per cent with a 10-sample group with next to the lowest weight-loss per cent which creates excessive inconstancy of data and therefore no significance. 
By a third test in Series 2, it was found that the omission of the separation of white oak from red oak wood threw together weight-loss data with great differences both in reaction to the decay organisms and to the site qualities and therefore had no significance.

The results of the fourth test in Series 2 are shown in Figure 5. The lack of pparation of $L$. trabea from $P$. versicolor data even though there are great differences between their weight-loss per cents in the decay of the two host

FIGURE 4. Weight losses resulting from decay of oak samples separated into eight groups according to decay organisms, host oak species, and site qualities. Each value is an average of 20 samples.

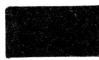

L. Trabea

P. Versicolor

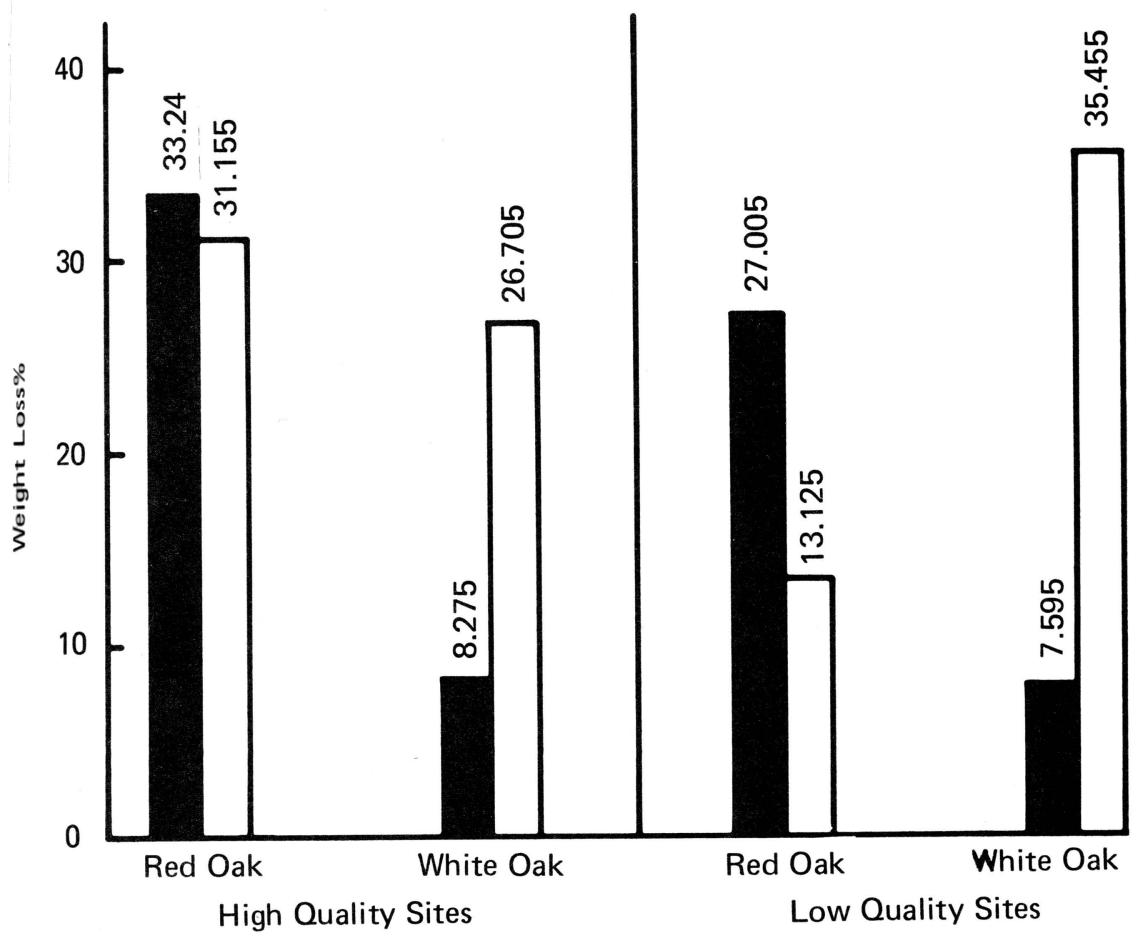


woods did not prevent a significance at the 1 per cent level. This graph empha sizes the great resistance to decay of both host woods to both decay organisms when the wood comes from sandstone low-quality sites.

The Series 2 tests in which the separation of the two variants of one of the four characteristics was omitted in each test resulted in significance at the 1 per cent level when the separation of the rock types and the decay organism were omitted but "no significance" when the site qualities and the host woods remained unseparated. Therefore it would appear that these two latter factors are of greater significance in determining the decay resistance of oak.

In the third series of six tests by analysis of covariance, the two variants of two characteristics are separated and the two variants of the other two characteristics remain dispersed. The "significant" results are shown in Figures 6 , 7 , and 8.

In the first test of Series 3, the lack of separation of the host woods and the decay organisms into different groups causes such inconstancy of data that any significance is masked. When the host woods were also separated as in Figure 5, the test results become significant because such prominent inconstancies as occur in the data from the combined red oak and white oak samples from high-quality limestone sites have been avoided by separating them.

The second test, Series 3, resulted in no significance because the site qualities have not been separated. If they are also separated as in Figure 5, the results become significant. It may be seen that the added separation of the decay fungi instead of the site qualities or the host species as in the second test in Series 2 does not make the test results significant. If the separation of the decay fungi is substituted for the separation of limestone from sandstone sites as in Figure 4, the results are significant.

The results of the third test in Series 3, shown in Figure 6, are particularly interesting. When wood samples come from high-quality sites, the red oak is nearly twice as susceptible to decay as the white oak, and when the wood samples come from low-quality sites, the white oak is a little more susceptible to decay than the red oak. As shown in Figure 5, this is due principally to the high decay resistance of white oak on high-quality, limestone sites and its very low decay resistance on low-quality, limestone sites.

In Figure 7, the fourth test of Series 3 shows that in spite of great differences in the data, oak wood from limestone sites had less decay resistance than wood from sandstone sites and that oak wood from either site was less resistant to $P$. versicolor than it was to $L$. trabea.

In the fifth test of Series 3, the averages of the weight-loss per cents of all oak samples from high-quality sites and from low-quality sites decayed by $L$. trabea and by $P$. versicolor were separated into different groups; it is known from the results of other tests that red and white oak have lesser decay resistance on high-quality sites; however, the inclusion of samples of white oak with those of 
FGURE 5. Weight losses caused by decay of oak samples separated into eight mups according to parent rock types, to site quality and to host oak species. ach value is an average of 20 samples.

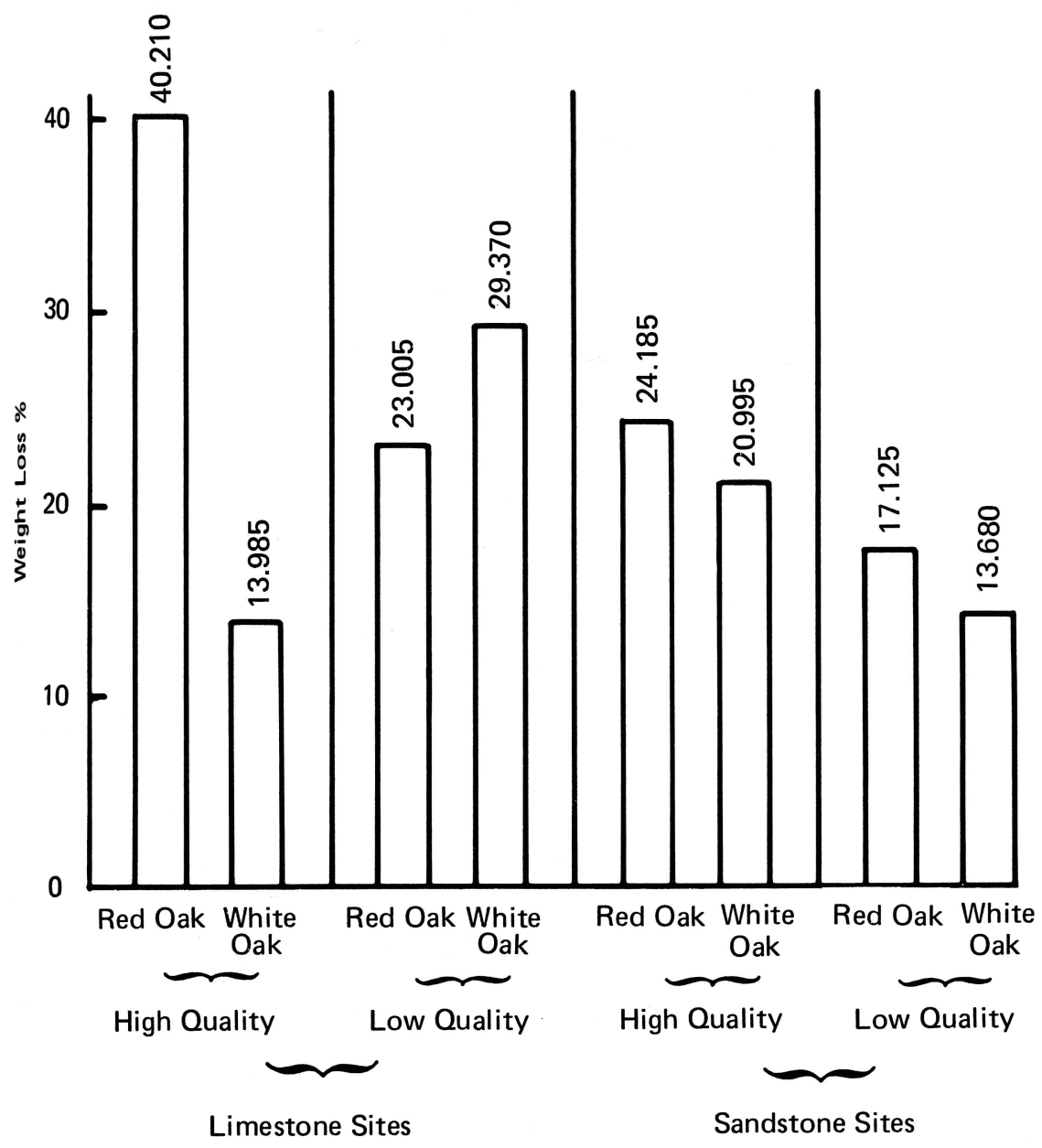


FIGURE 6. Weight losses caused by decay of oak samples separated into fou groups according to quality of site, high-quality and low-quality, and hoot woods, red oak and white oak. Each value is an average of $\mathbf{4 0}$ samples.

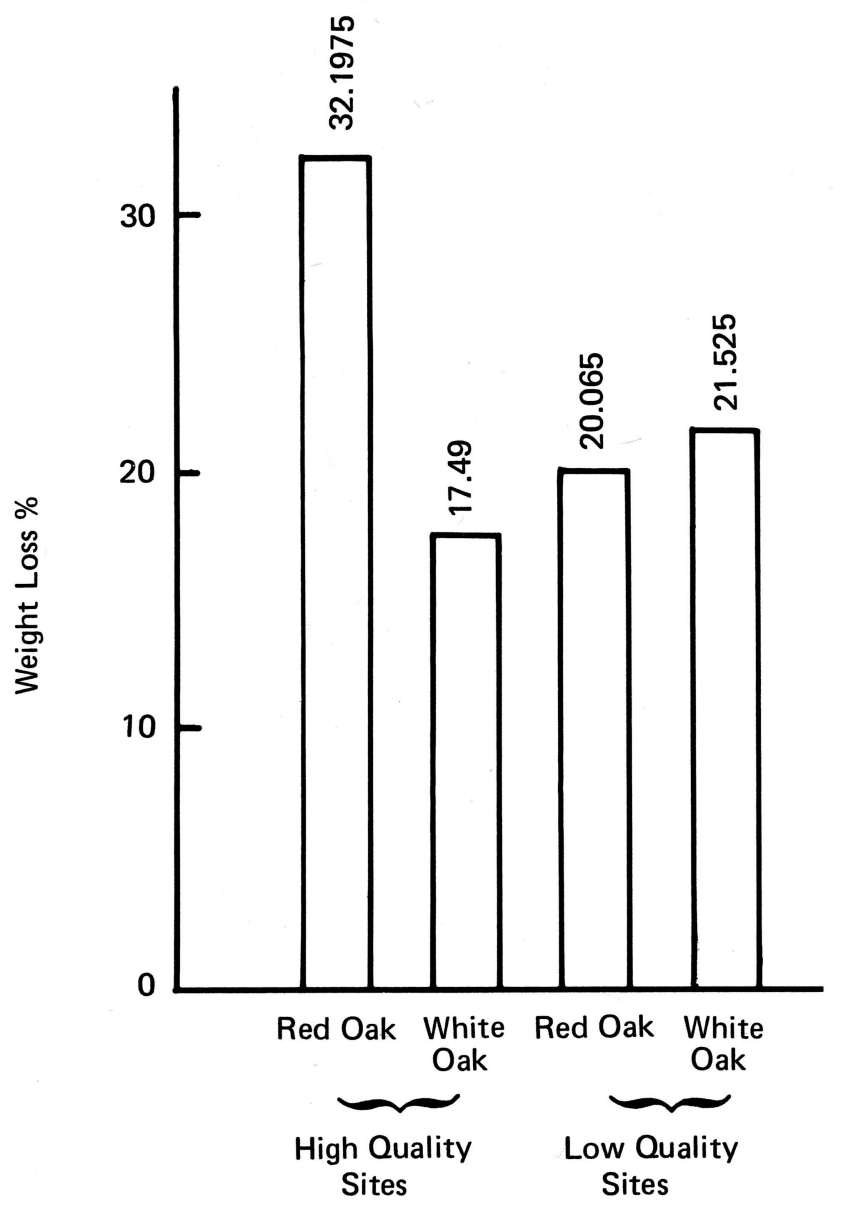


IGURE 7. Weight losses resulting from decay of oak samples separated into wur groups according to parent rock type of the sites and to decay organisms. bch value is an average of $\mathbf{4 0}$ samples.
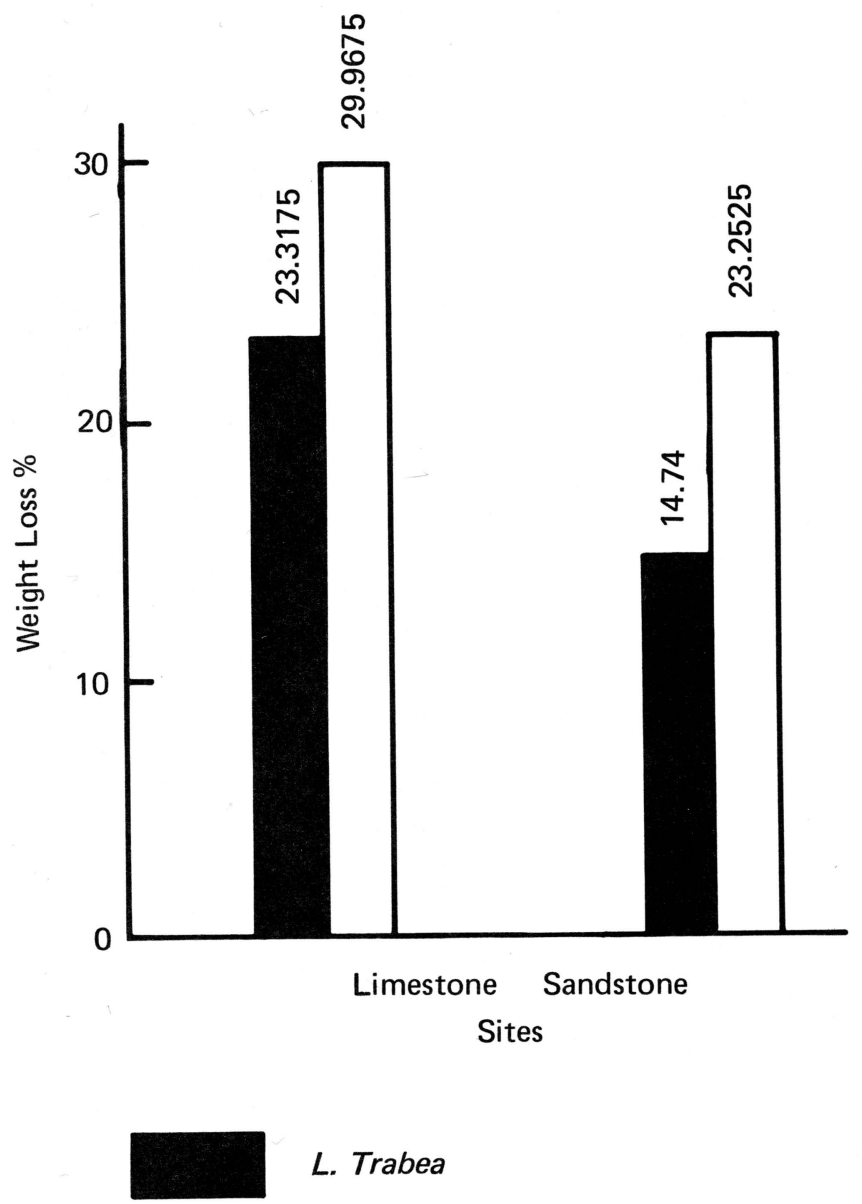

L. Trabea

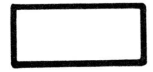

P. Versicolor 
FIGURE 8. Weight losses resulting from decay of oak samples separated into four groups according to host oak species and to decay organisms. Each value is an average of $\mathbf{4 0}$ samples.

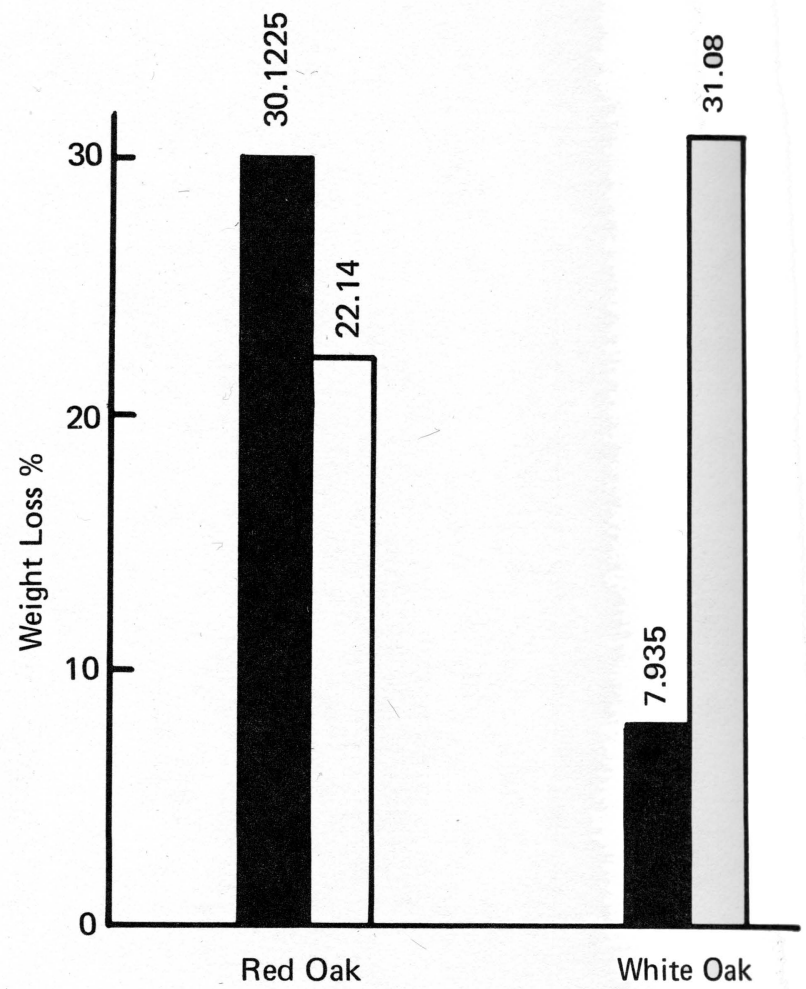

Wood

L. Trabea

P. Versicolor 
red oak, both from limestone sites with their vigorous and opposite reactions causes "no significance." If these data were further separated into red oak and white oak 20-sample groups the constancy would be improved as in Figure 4 where the differences are significant at the 1 per cent level.

Figure 8 shows the mean weight-loss per cents caused by each decay fungus upon each host wood. Figure 2 shows that there is no site used in this study where $P$. versicolor caused as much decay of red oak as $L$. trabea or where $L$. trabea caused half as much decay of white oak as $P$. versicolor.

\section{CONCLUSIONS}

The data presented indicate that site characteristics have a highly significant effect upon decay resistance of red and white oak wood. $L$. trabea and $P$. versicolor decayed red oak wood more rapidly when it had grown on moist, high-quality sites than on dry, low-quality sites. These site characteristics had the same effect upon white oak when grown on sandstone sites, however, the effect was just the opposite on limestone sites. The decay effects of both fungi were sharply inhibited by white oak wood from high-quality, limestone sites. $P$. versicolor caused a greater weight-loss per cent to white oak samples from a low-quality, limestone site than that caused to any other group of cores in this study. This explains the observations made by timber buyers which was mentioned in the introduction. (Buyers who wanted durable white oak looked particularly for it growing on fertile limestone soils.)

L. trabea caused an average per cent weight loss of approximately 30 per cent of red oak samples from all sites. $P$. versicolor caused an average per cent weight loss of white oak samples from all sites of approximately 31 per cent. $P$. versicolor decay was inhibited on the red oak cores to the extent of about $1 / 4$ the per cent weight loss caused by $L$. trabea, whereas $L$. trabea was inhibited on the white oak cores from all sites to the extent of about $3 / 4$ the per cent weight loss caused by $P$. versicolor.

The results of this study suggest that woods will generally decay more rapidly when grown on limestone sites than on sandstone sites and on high-quality sites than on low-quality sites. If such generality should be substantiated by further research, there still will be unique exceptions, particularly where natural toxic substances such as tannin or structures such as tyloses in the wood may affect the actions of decay organisms. 


\section{LITERATURE CITED}

Anonymous. 1950. Factors That Influence the Decay of Untreated Wood in Service and Comparative Decay Resistance of Different Species. USDA, Forest Service, Forest Prods. Lab. Rept., R68 (rev.): 1-5.

Boyce, J. S. 1961. Forest Pathology (3rd ed.), 572 pp. McGraw-Hill Book Company, Inc, New York.

Boyce, J. S. and J. W. B. Wagg. 1953. Conk Rot of Old-growth Douglas Fir in Western Oregon. Oregon Forest Products Lab. (Corvallis) Bull. 4: 1-96.

Hartley, Carl. 1958. Evaluation of Wood Decay in Experimental Work. USDA, Forest Serivce, Forest Products Lab. Report No. 2119.

Merrill, W. and E. B. Cowling. 1966. "Role of Nitrogen in Wood Deterioration. IV. Relationship of Natural Variation in Nitrogen Content of Wood to Its Susceptibility to Decay." Phytopathology 56: 1324-1325.

Panshin, A. J. and Carl DeZeeuw. 1970. Textbook of Wood Technology (3rd ed), Vol. 1, 705 pp. McGraw-Hill Book Company, Inc., New York.

Scheffer, T. C., G. H. Englerth and C. G. Duncan. 1949. “Decay Resistance of Seven Native Oaks." J. Agr. Res. 78: 129-152.

Southam, C. M. and J. Ehrlich. 1943. “Decay Resistance and Physical Characteristics of Wood." J. Forestry 41: 666-673.

Toole, E. Richard and W. N. Darwin, Jr. 1970. Influence of Variation in Physical and Chemical Properties of Southern Red Oak Lumber on Decay Resistance. Mississippi State University Forest Products Utilization Lab. Research Report No. 10.

Tsoumis, George. 1968. Wood as a Raw Material. 276 pp. Pergamon Press, New York.

Yawney, H. W. 1964. Oak Site Index on Belmont Limestone Soils in the Allegheny Mountains of W. Va. U.S. Forest Service Research Paper NE-30.

Zabel, R. A. 1948. Variations in the Decay Resistance of White Oak. N. Y. State College of Forestry Tech. Pub. No. 68, 53 pp. 
[Blank Page in Original Bulletin] 
[Blank Page in Original Bulletin] 